\title{
Evaluation of the epidemiological aspects and the impact of COVID-19 on tuberculosis notifications in São Paulo ${ }^{a}$
}

\author{
Talita Antunes Antoniolli Pontes ${ }^{1}$ (1), Renan Augusto Ramos ${ }^{2}$ (i) , Janine Pedroso Scolaro ${ }^{3}$ (1), \\ Fernanda Stumpf Tonin ${ }^{4}$ (1), Bruno Salgado Riveros ${ }^{5}$ (D), Astrid Wiens ${ }^{6 *}$ (1)

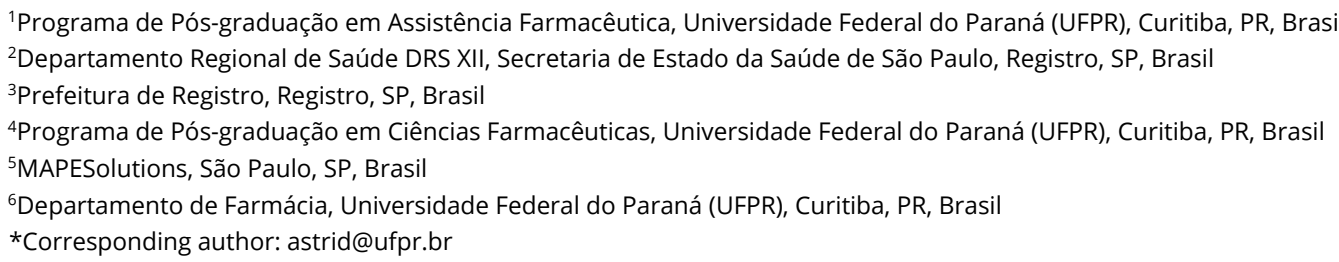

\begin{abstract}
Objective: This study aimed to analyze the incidence and epidemiological profile of tuberculosis (TB) cases registered in a region of the State of São Paulo (SP) and to assess the impact of COVID19 on TB incidence and completeness of notifications. Methods: This is a retrospective crosssectional study analyzing reports of adult patients with TB, who were notified in the TB-Web from January 2010 to December 2020. Sociodemographic (e.g. sex, race and scholarity) and clinical variables (e.g., clinical form, types of cases and comorbidities) were collected and analyzed. The completeness of TB notifications and the impact of COVID-19 on TB notifications were evaluated, considering the year of 2020. The study was reported following Strengthening the Reporting of Observational Studies in Epidemiology (STROBE) checklist for cross-sectional studies [CAAE 33166620.0.0000.0102]. Results: A total of 1,509 notifications were included, with a mean incidence of $48.5 / 100,000$ inhabitants. The median age was 42 years, most notification included males $(71 \%)$, were of white race $(42 \%)$ and had the pulmonary form of TB $(85 \%)$. In assessing the impact of the pandemic on notifications in 2020, there was a decrease of $36 \%$ in the number of TB notifications, with an emphasis between July and August, which was the peak period of COVID-19 cases in the region. No change in the completeness of TB notifications was observed in this period. Conclusions: Results indicate the clinical and epidemiological profile in a region of SP between 2010 and 2020. The pandemic led to a decrease in the number of TB notifications but did not change the completeness of notifications.
\end{abstract}

Keywords: Tuberculosis. Epidemiological Monitoring. Health Profile. Cross-Sectional Study. Coronavirus.

\section{How to cite}

Pontes TAA, Ramos RA, Scolaro JP, Tonin FS, Riveros BS, Wiens A. Evaluation of the epidemiological aspects and the impact of COVID-19 on tuberculosis notifications in São Paulo. Rev Ciênc Farm Básica Apl. 2021;42:e754. https://doi.org/10.4322/2179-443X.0754.

a All information obtained as a result of the study is included in the manuscript.

Financial support: This study was financed in part by the Coordenação de Aperfeiçoamento de Pessoal de Nível Superior - Brasil (CAPES) - Finance Code 001 Conflicts of interest: All authors declare that there is no conflict of interest.

The study was carried out at Universidade Federal do Paraná (UFPR), Curitiba, PR, Brasil.

Received on August 30, 2021. Accepted on October 07, 2021. 


\section{INTRODUCTION}

Tuberculosis (TB), caused by Mycobacterium tuberculosis, is considered one of the oldest infectious diseases of humanity. In 2018, there were an estimated 10 million new cases of TB worldwide, and 1.5 million people died from the disease. In the same year, in Brazil, the incidence of TB was 45 cases per 100,000 inhabitants, and the disease-related mortality rate was 2.3 deaths per 100,000 inhabitants'.

Brazil occupies 30th place on the list of countries with the highest load of $\mathrm{TB}^{2}$. In the country, TB is a mandatory notification disease through the information system called Sistema de Informação de Agravos de Notificação (Sinan-TB) ${ }^{3}$. Each year, in Brazil, approximately 80,000 new cases of TB are reported; in 2019, there were 73,864 incident cases ${ }^{4}$ and, about 4,500 deaths from the disease, with a mortality rate of 2.2 deaths per 100,000 inhabitants. In 2020, Brazil registered 66,819 new cases of TB, with an incidence rate of 31.6 cases per 100,000 inhabitants 5 .

In 2017, the Ministry of Health (Ministério da Saúde - MS), in accordance with the Strategy for the End of TB of the World Health Organization (WHO), prepared the National Plan for the End of TB as a Public Health Problem, which reaffirms the Brazilian commitment to confront the problem, highlighting the intention to reduce the incidence rate to less than 10 cases per 100,000 inhabitants and the TB mortality rate to less than 1 death per 100,000 inhabitants by the year $2035^{6}$.

In December 2019, the first cases of a new infectious disease, called COVID-19, transmitted by a new coronavirus, SARS-CoV-2, were identified in Wuhan, China. The rapid spread of the virus worldwide, with clinical spectrums ranging from asymptomatic infections to severe conditions, led to the decree of the pandemic ${ }^{7}$. In Brazil, the first case of COVID-19 was registered in February 2020, and by September 2021, more than 591,440 lives had been lost, and more than 21 million cases had been reported ${ }^{8}$. With the pandemic, there was a need to change the reorganization of health services to simultaneously face the pandemic and maintain the regular supply of its actions ${ }^{9}$.

COVID-19 has the potential to substantially impact the control of a range of diseases. In addition to overburdening health systems, there is concern that, due to poor health and fear of contracting COVID-19, individuals will not seek medical care when a health problem arises ${ }^{10}$. Coronavirus disease has disrupted TB services worldwide. The Global Tuberculosis Network global study evaluated 33 centres in 16 countries and observed that most centres had reductions during the first 4 months of the COVID-19 pandemic in TB-related hospital discharges, newly diagnosed cases of active TB, total active TB outpatient visits and newly diagnosed latent TB infections (and related outpatient visits) when compared to in the same period in 2019. In addition, decreased attendance to TB clinics was associated with the patient's fear of exposure to COVID-19 in the community, interruptions in services or difficulty in accessing health services during the lockdown ${ }^{11}$. In South Korea, the negative effect of the outbreak of COVID-19 on TB was not limited to diagnosis, as outpatient clinics and emergency departments were temporarily closed after patients visiting the facility were identified as having COVID-1912. In Brazil, the 2020 data presented in the Tuberculosis Epidemiological Bulletin, published in March 2021, demonstrated a different behaviour in relation to the historical series of TB, and some important changes in the epidemiological and operational indicators were observed, such as a sharp decline in incidence, and a worsening of indicators, such as an increase in dropout rates and a reduction in the total number of TB notifications ${ }^{5}$.

Therefore, the aim of this study was to analyze the incidence, epidemiological profile and completeness of notifications of TB cases registered at the Regional Health Department 12 (DRS XII - Departamento Regional de Saúde) of the state of São Paulo (SP) in the last 10 years and to assess the collateral impact of the COVID-19 pandemic on TB notifications. 


\section{MATERIAL AND METHODS}

\subsection{Study design}

This is a retrospective, cross-sectional study to analyze the notifications of patients diagnosed with TB that was carried out in a region of the state of SP from January 2010 to December 2020. This study was conducted and reported in accordance with the Strengthening the Reporting of Observational Studies in Epidemiology (STROBE) guidelines for observational studies ${ }^{13}$. This study was approved by the Research Ethics Committee of the Health Sciences Sector of the Universidade Federal do Paraná under protocol number 4.177.730 (CAAE 33166620.0.0000.0102).

\subsection{Setting}

The DRS XII, located in the Vale do Ribeira region, southeast of the state of SP, has a population of approximately 284,469 inhabitants, distributed in 15 municipalities (Barra do Turvo, Cajati, Cananéia, Eldorado, Iguape, Ilha Comprida, Iporanga, Itariri, Jacupiranga, Juquiá, Miracatu, Pariquera-Açu, Pedro de Toledo, Registro and Sete Barras). The set of these municipalities occupies a territory just under $5 \%$ of the area of the state of SP, Brazil, with low population density.

\subsection{Participants}

\section{Inclusion criteria}

Notifications of adult individuals (over 18 years of age) who were diagnosed with TB between January 2010 and December 2020 and notified in the DRS XII were included.

\section{Exclusion criteria}

Notifications that did not present the date of birth were excluded.

\subsection{Variables}

The following sociodemographic variables were collected: gender, age, place of birth, race, education, neighbourhood and city of origin, complementary data (such as types of cases [new, relapse, retreatment and previous treatment terminated by failure/resistance/toxicity]), sequence treatment, type of occupation (housewife, detainee, health professional, unemployed and retired) and institution (penal institution, refuge, asylum, orphanage, psychiatric hospital or support house). These variables were collected by the health professional at the time of the consultation, which could be through verification of documents (gender, age, place of birth, proof of address and institution), self-report (race, education and occupation) or medical records (type of cases and treatment sequence).

Clinical variables were collected, including the criteria for confirmation of TB, type of discovery (active search in an institution, active search in the community, outpatient demand, discovery after death, elucidation diagnosed in hospitalization, investigation of contacts and urgency/emergency), incidence, onset of first symptoms, date of diagnosis, initial treatment, change in treatment, sensitivity and resistance tests, clinical forms of TB (pulmonary and extrapulmonary) and associated diseases and conditions. Comorbidities were also collected by TB-Web, in addition, alcoholism, smoking and drug abuse were classified according to the criteria of the health professional at the time of clinical evaluation. 


\subsection{Data sources/management}

Data on patients with TB from the DRS XII were extracted from the TB Patient Control System (TB-Web), an online information system, exclusive in the state of SP, which stores the medical records from TB notifications.

The information from the TB notification forms were transferred in a single file, via the Internet, to the TB-Web and to the Sinan-TB, which is a national system available for consultation in the DATASUS (Brazilian Public database - Departamento de Informática do Sistema Único de Saúde).

Data were extracted from TB-Web between August 2020 and January 2021, and collected in Microsoft Excel ${ }^{\circledR}$ spreadsheets, maintaining the confidentiality of patients (only with the initials of patients and their dates of birth). Three researchers participated in the data collection process.

To assess the impact of COVID-19 on TB notifications in DRS XII, the numbers of COVID-19 cases were searched for in SIVEP GRIPE, a system used by the epidemiological surveillance of state and municipal authorities to track cases of the flu and severe acute respiratory syndrome for each month of the year 2020.

The completeness of notifications was also assessed for each year. The completeness analysis was based on an item-by-item assessment of the filling in of the variables present in the TB notification forms. The number of items not completed in each notification were quantified.

\subsection{Statistical methods}

Descriptive data analyzes were conducted using absolute and relative frequencies to report categorical variables. Normal variables were reported as means and standard deviations, while non-normal variables were reported as medians and interquartile ranges. The incidence of notifications was calculated by calculating the number of notifications per year per 100,000 inhabitants.

The T test of two independent samples was used to assess the impact of COVID-19 on the completeness of notifications, comparing the year 2020 to other years (2010 to 2019). For continuous variables, normality was assessed using Kolmogorov-Smirnov, Shapiro-Wilk and exploratory Q-Q graphs. Significance measures were obtained by testing the null hypothesis ( $p$ value), considering significant results when $p<0.05$.

To assess the impact of the COVID-19 pandemic on the incidence of TB, the T test of two independent samples was used, comparing the year 2020 to other years (2010 to 2019) or to the year 2019 through the IBM SPSS Statistics v.22 program. An ANOVA test was also performed, which evaluated the means considering the COVID-19 cases per month vs. the number of TB notifications. Spearman's rho was used to assess the correlation between year of notification and incidence.

\section{RESULTS}

\subsection{Epidemiological aspects}

Between January 2010 and December 2020, 1,625 diagnosed cases of TB were reported on the TB-Web, an average of 148 cases per year in the region covering the DRS XII. After applying the eligibility criteria, which excluded 114 children under 18 years of age and two notifications without date of birth, TB notifications were obtained from 1,509 patients, who were included in the study and had their data extracted. It was observed that most notifications occurred in $2017(n=164), 2018(n=160)$ and $2019(n=183)$ (Figure 1). 


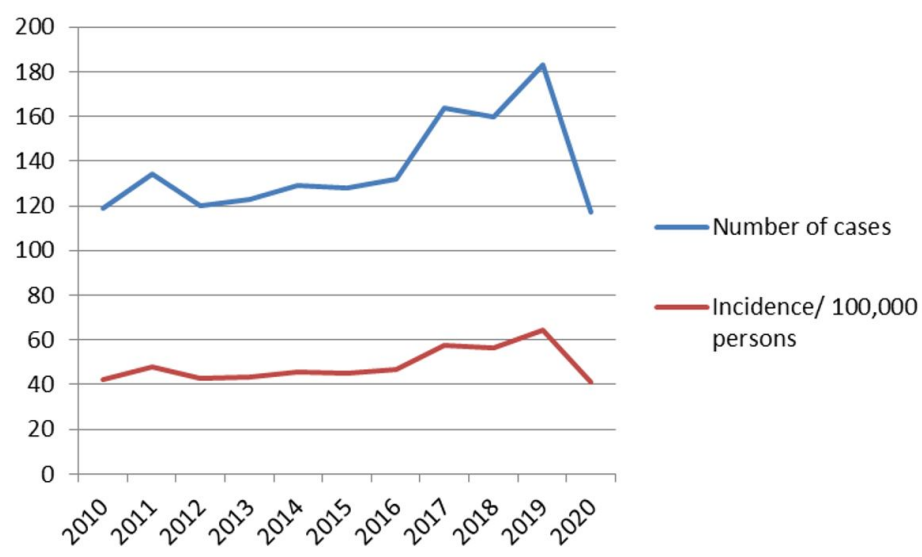

Figure 1. Incidence of tuberculosis in the Regional Health Department (DRS) XII, from 2010 to 2020.

Regarding sociodemographic characteristics (Table 1), the median age was 42 years (interquartile range from 28 to 54 years) and the prevalence was higher in males (71\%) and in whites (42.9\%). Education was not filled out in about one third (31\%) of the notifications; $25 \%$ of patients reported 4 to 7 years of education, corresponding to incomplete primary education. About $96 \%$ of the cases were not institutionalized, and $18.5 \%$ of the cases were unemployed.

Table 1. Socio-demographic characteristics of the included population.

\begin{tabular}{|c|c|c|c|}
\hline \multicolumn{2}{|c|}{ Variable } & \multicolumn{2}{|l|}{$N=1,509$} \\
\hline \multicolumn{2}{|c|}{ Median age (IQR) } & \multicolumn{2}{|c|}{$41(28-54)$ years } \\
\hline \multirow[t]{3}{*}{ Sex } & Male & 1070 & $71.0 \%$ \\
\hline & White & 648 & $42.9 \%$ \\
\hline & Brown & 470 & $31.2 \%$ \\
\hline \multirow{7}{*}{ Race } & Black & 112 & $7.4 \%$ \\
\hline & Yellow & 21 & $1.4 \%$ \\
\hline & Indigenous & 5 & $0.3 \%$ \\
\hline & NR & 253 & 16.8 \\
\hline & 4 to 7 years & 377 & $25.0 \%$ \\
\hline & 8 to 11 years & 367 & $24.3 \%$ \\
\hline & 1 to 3 years & 130 & $8.6 \%$ \\
\hline \multirow[t]{6}{*}{ Scholarity } & 12 to 14 years & 74 & $4.9 \%$ \\
\hline & No education & 44 & $2.9 \%$ \\
\hline & $>15$ years & 42 & $2.8 \%$ \\
\hline & NR & 475 & $31.5 \%$ \\
\hline & No & 1448 & $96.0 \%$ \\
\hline & Penal institution & 25 & $1.7 \%$ \\
\hline \multirow{7}{*}{ Institution } & Asylum & 2 & $0.1 \%$ \\
\hline & Refuge & 2 & $0.1 \%$ \\
\hline & Psychiatric Hospital & 1 & $0.1 \%$ \\
\hline & NR & 31 & $2.0 \%$ \\
\hline & Other & 670 & $44.4 \%$ \\
\hline & Unemployed & 278 & $18.5 \%$ \\
\hline & Housewife & 164 & $10.9 \%$ \\
\hline \multirow[t]{4}{*}{ Occupation } & Retiree & 128 & $8.5 \%$ \\
\hline & Inmate & 34 & $2.2 \%$ \\
\hline & Health professional & 22 & $1,5 \%$ \\
\hline & $\mathrm{NR}$ & 213 & $14.0 \%$ \\
\hline
\end{tabular}

$\mathrm{N}=$ number of notifications. SD = standard deviation. $\mathrm{NR}=$ not reported. 
Regarding the incidence by city, Registro stood out with the highest number of cases $(n=364 ; 24.12 \%)$, followed by Iguape $(n=194 ; 12.86 \%)$ and Cajati $(n=136 ; 9.01 \%)$.

Most TB cases ( $n=1,282 ; 85 \%$ ) were classified as pulmonary (Table 2$)$. In $70 \%(n=1,055)$ of the cases, sputum smear microscopy was performed to diagnose the disease, with $18 \%$ $(n=267)$ with a negative result and $12 \%(n=187)$ without a result. New TB cases represented $82.2 \%(n=1,240)$ of the sample. About half of the diagnoses $(n=847 ; 56.1 \%)$ were performed during outpatient visits (service in primary care through health units). AIDS was found in $4.7 \%$ $(n=71)$ of cases. The main comorbidities or conditions found in the patients were alcoholism (22.2\%), smoking (18.8\%), drug addiction (12.7\%) and diabetes (6.4\%).

Table 2. Tuberculosis clinical data reported in the included notifications.

\begin{tabular}{|c|c|c|c|}
\hline & Variables & $\mathrm{N}=1,509$ & $\%$ \\
\hline \multirow{3}{*}{ Clinical form } & Pulmonary & 1.282 & $85.0 \%$ \\
\hline & Extrapulmonary & 203 & $13.4 \%$ \\
\hline & Pulmonary + extrapulmonary & 24 & $1.6 \%$ \\
\hline \multirow{4}{*}{$\begin{array}{l}\text { Criteria for diagnostic } \\
\text { confirmation }\end{array}$} & Positive sputum smear microscopy & 1055 & $70.0 \%$ \\
\hline & No bacteriological confirmation & 391 & $25.9 \%$ \\
\hline & Culture & 54 & $3.5 \%$ \\
\hline & $\begin{array}{l}\text { Positive sputum smear microscopy - other } \\
\text { material }\end{array}$ & 9 & $0.6 \%$ \\
\hline \multirow{6}{*}{ Case type } & New & 1240 & $82.2 \%$ \\
\hline & Relapse & 154 & $10.2 \%$ \\
\hline & Retreatment after abandonment & 107 & $7.1 \%$ \\
\hline & Retreatment after failure or resistance & 6 & $0.4 \%$ \\
\hline & Retreatment after intoxication & 2 & $0.1 \%$ \\
\hline & Outpatient & 847 & $56.1 \%$ \\
\hline \multirow{5}{*}{ Discovery type } & Urgency / Emergency & 332 & $22.0 \%$ \\
\hline & Diagnostic elucidation in hospitalization & 204 & $13.5 \%$ \\
\hline & Contact investigation & 27 & $1.8 \%$ \\
\hline & Active community search & 24 & $1.6 \%$ \\
\hline & Active search in institution & 11 & $0.7 \%$ \\
\hline \multirow{11}{*}{ Comorbidities } & Discovery after death & 2 & $0.1 \%$ \\
\hline & NR & 62 & $4.2 \%$ \\
\hline & Alcoholism & 335 & $22.2 \%$ \\
\hline & Smoking & 284 & 18.8 \\
\hline & Drug addiction & 192 & $12.7 \%$ \\
\hline & Other & 132 & $8.7 \%$ \\
\hline & Diabetes & 96 & $6.4 \%$ \\
\hline & AIDS & 71 & $4.7 \%$ \\
\hline & Mental disease & 37 & $2.4 \%$ \\
\hline & Immune disease & 27 & $1.8 \%$ \\
\hline & NR & 487 & $32.3 \%$ \\
\hline
\end{tabular}

$\mathrm{N}=$ number of notifications. $\mathrm{NR}=$ not reported.

Regarding treatment, $95.6 \%$ of the patients initially received the standardized TB treatment scheme recommended by the Brazilian Ministry of Health, which is rifampicin + isoniazid + pyrazinamide + ethambutol. The regimen was self-administered in $54.4 \%$ of patients, while $36.1 \%$ of patients were supervised by health professionals. 


\subsection{Assessment of the impact of COVID-19 on TB notifications}

From the beginning of the pandemic in March 2020 to December 2020, 86 cases of TB and 11,733 cases of COVID-19 were reported in the evaluated region. Figure 2 shows the incidence graph of the monthly average number of TB cases reported in 2020, TB cases during 20102019, and COVID-19 cases reported in 2020. According to the ANOVA test, the means considering the cases of COVID-19 per month vs. the number of TB notifications (2010-2019 $=$ "before 2020" vs. "after 2020") were without statistical difference.

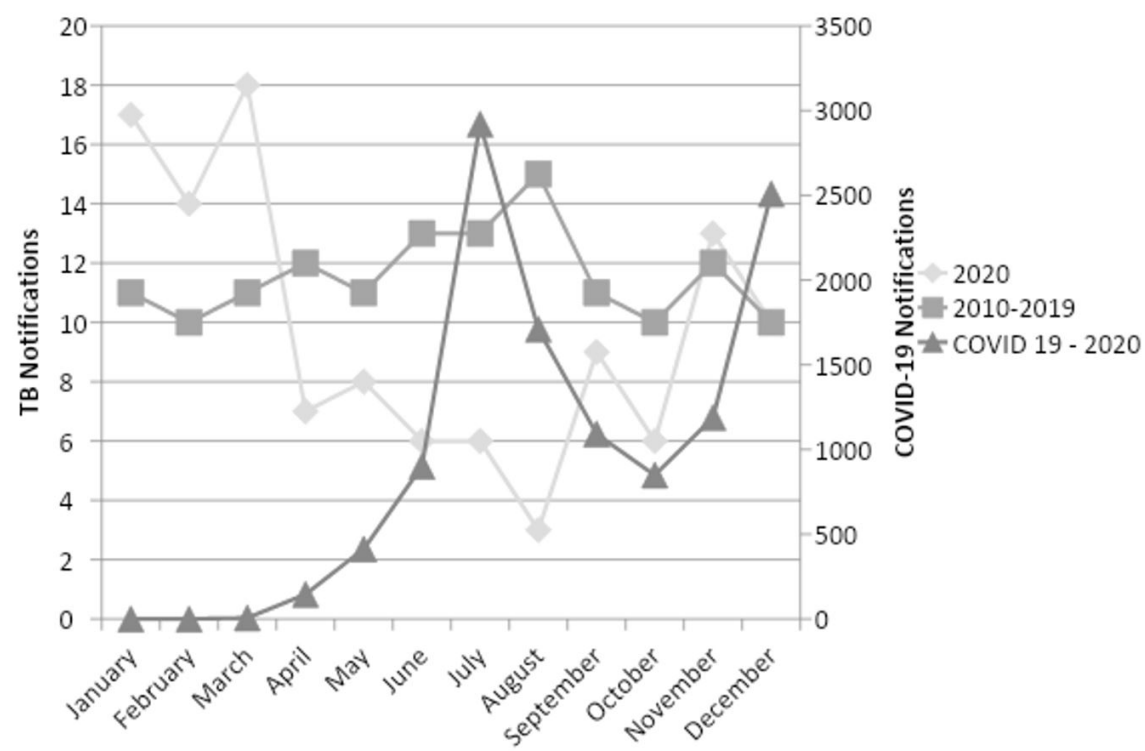

Figure 2. Incidence of tuberculosis and COVID-19 cases in the Regional Health Department (DRS) XII.

According to the T-test analysis of independent samples, considering the groups "20102019 vs. 2020 " or "2019 vs. 2020", in both cases, there was a significant difference in the variable "incidence per 100,000 inhabitants" (which takes into account the number of notifications per year). In 2020, notifications decreased significantly $(p<0.0001)$. There was also a moderate and significant correlation (Spearman's rho: $0.430 ; p<0.0001$ ) between the year of notification and the incidence (number of notifications).

Compared to 2019, there was a 36\% decrease in the number of TB notifications in 2020 when the pandemic began in Brazil. Comparing July 2019 to July 2020, there was a reduction of $73 \%$, as well as a reduction of $84 \%$ in August, in the number of TB notifications. During this same period, there was a peak in cases of COVID-19 reported in this region.

In the statistical analysis, using the $T$ test of two independent samples, there was no difference in the completeness of TB notifications $(p=0.109)$ between the periods $2010-2019$ vs. 2020.

\section{DISCUSSION}

In this study, it was possible to assess the clinical and epidemiological profiles of approximately 1,500 adults diagnosed with TB in a region of SP, Brazil, and the significant impact of the COVID-19 pandemic on TB notifications.

Knowledge of the profile of individuals with TB is essential to allow more assertive prevention and treatment measures in the country and to achieve the goals proposed by the WHO. The Manual of Recommendations for the Control of Tuberculosis in Brazil recommends carrying out studies and analyzes in various areas of the country, helping to better define TB variables and parameters, in order to obtain a scenario closer to the national reality, enabling comparisons of data from TB control programs. The average TB growth coefficient found in 
this region was 48.8 per 100,000 inhabitants between 2010 and 2020, from 56.3 per 100,000 inhabitants in 2018 to 64.3 per 100,000 inhabitants in 2019, representing an increase of $14.2 \%$ in new cases of the disease. In Bahia, in a study carried out on the clinical and epidemiological profiles from 2014 to 2019, there was also an increase in the incidence rate in 2019 (23.7 cases per 100,000 inhabitants) representing $3 \%$ of the new cases of the disease when compared to 2014 ( 23.0 cases per 100,000 inhabitants) ${ }^{14}$. This could have occurred because the Ministry of Health, in 2018, distributed rapid molecular tests for TB, an expansion of access to diagnostic tools, which could have contributed to the increase in the number of TB notifications, and consequently, in the incidence rate ${ }^{15}$.

TB is a disease of young adults, predominantly in males, as previously reported in other national and international studies ${ }^{16,17}$. Although other Brazilian studies describe that the disease mostly affects individuals of the brown/black race (rates of $77 \%$ and $60 \%$ in the studies by Tavares $^{18}$ and in the integrative review by Macedo ${ }^{19}$, respectively), in our study, the white race was predominant, (with 43\%). Furthermore, the incidence of the brown race was about $32 \%$. This is probably due to the constitution of the population in the place of analysis, which are regions that had a large immigration of Europeans. Another study evaluated the epidemiological profile of TB in the northeast region of Brazil over the past 5 years. In this study $68 \%$ were male, aged between 20 and 39 years, which was equivalent to $43 \%$ of cases, followed by individuals aged 40 to 59 years, representing $32 \%$ of cases. The most prevalent clinical form of TB in the period was pulmonary (86\%), 9,550 (14\%) had AIDS, 10,269 (16\%) had diabetes, 22,019 (34\%) were smokers, and 23,237 (6\%) used alcohol ${ }^{20}$.

Low education is one of the factors most associated with the incidence of TB in the population, due to the precariousness of life and lack of access to information. Low education can negatively influence the understanding of the importance of correct treatment and the risks of abandoning anti-TB therapy ${ }^{21,22}$. As in the study by Macedo et al. ${ }^{19}$, we found that about one third of patients with TB had a low educational level. It is also noteworthy that $31 \%$ of the notifications were not filled in for the field "schooling", which indicates an important weakness of the local surveillance system for the epidemiological analysis of the educational and social levels ${ }^{23,24}$. Other studies point to important challenges for surveillance of TB due to the low completeness of the fields of the notification form and the precariousness of information on diagnosis and follow-up. The low quality of information, in addition to compromising the adequate knowledge of the epidemiological profile of the cases, prevents the assessment of surveillance actions, as it is not possible to identify whether the noncompletion is due to deficiencies in surveillance actions or in their registration ${ }^{25,26}$.

Pulmonary is usually the most prevalent form of TB, being diagnosed by sputum smear microscopy the most frequently, as evidenced in the study conducted in the state of Alagoas (northeastern Brazil) with rates of $86.32 \%$ and $52.33 \%$, respectively ${ }^{18}$. The treatment of TB cases followed WHO protocols that were already well-established worldwide due to their high efficacy and long-term safety (e.g., with combined therapies based on rifampicin and isoniazid) ${ }^{2}$. Cases of co-infection and comorbidities of TB are common and must be critically evaluated by the clinical team in order to choose the best treatment. HIV infection is one of the main risk factors for the evolution of latent disease caused by $M$. tuberculosis due to changes in the human body's defense mechanisms against the causal agent of TB'. In 2019, in Brazil, 9.85\% new positive cases of TB and HIV co-infection were confirmed ${ }^{19}$.

Before the COVID-19 pandemic, many countries made significant progress in the management of TB cases. However, service disruptions caused by the pandemic have led to setbacks; negative impacts were reported in disease data collection and reporting systems. Human and financial resources were reallocated to the response to COVID-19. According to the new WHO report, data collected from more than 200 countries showed significant reductions in TB case reports, with falls of $25-30 \%$ reported in three countries with high disease burden (India, Indonesia and the Philippines) between January 2020 and June 2020 compared to the same 6-month period in 2019. These reductions in case reports could lead to a dramatic increase in deaths from $\mathrm{TB}^{27}$. 
In Brazil, only in 2020, there were 66,819 new cases of TB, with an incidence rate of 31.6 cases per 100,000 inhabitants. Compared to 2019 , there was a $9.5 \%$ decrease in the number of new cases of the disease 5. A Brazilian study evaluated the incidence of TB between 2006 and 2015, with the highest incidence in the north region (44.9 cases per 100,000 inhabitants), followed by the southeast, northeast, south and midwest regions (incidences of 39.8, 36, 2, 31.4 and 21.3 cases per 100,000 inhabitants, respectively) ${ }^{28}$. From 2006 to 2019 , the incidence in the state of SP varied between 34.8 and 40.6 cases per 100,000 inhabitants (in 2020, 16,086 people received TB notifications, with an incidence of 34.8 cases per 100,000 inhabitants). There are variations in incidence between the different regions of the state (baixada santista: 73.6-91.5 cases per 100,000 inhabitants; city of SP: 45.5-51.5 cases per 100,000 inhabitants; countryside cities: 19.1-22.8 cases per 100,000 inhabitants; and the Metropolitan Region: 30.5-35.5 cases per 100,000 inhabitants) ${ }^{29}$.

In our study, the percentage of reduction in notifications between 2019 and 2020 was 36\%, which occurred especially during the peak of the pandemic in the DRS XII. This may have been influenced, among other factors, by the behavior of the population in this region against the pandemic and by the restrictive decrees imposed by the state of SP during the initial period of the COVID-19 outbreak. Through correlation analyzes, it was possible to verify that there was an increase in TB notifications over the years 2010-2019; however, this was modified in 2020, when there was a decrease in TB notifications. Similar data were observed in South Korean, city of Daegu, which was the epicenter of the COVID-19 pandemic in that country, with a $24 \%$ reduction in TB notifications after the first coronavirus outbreak ${ }^{10}$. Decreases in the TB notification rates in early 2020 compared to the same period in the last 2-5 years were also reported in Shanghai (47. 8\%), Uganda (43\%), Nigeria (34\%), South Africa (33\%), Japan (33\%) and Taiwan $(20 \%)^{30}$.

The main hypotheses for the reduction in the number of TB notifications during the pandemic period may be related to the real decrease in cases, since TB is an infectiouscontagious disease whose transmission is reduced with preventive measures, such as social distancing and hygiene and cleaning care (use of face masks and alcohol gel) ${ }^{12}$. In another scenario, the reason is the overload of health services due to the high number of cases of COVID19 , resulting in severe reductions in the availability and access to these services for diagnosis and treatment of TB cases $^{31}$. In another more realistic scenario, health professionals involved in the care of patients with TB were assigned to care for patients diagnosed with coronavirus. As a result, a decrease in the investigation of latent TB in asymptomatic adults and adolescents in contact with individuals with active TB, which can lead to delays in the diagnosis and treatment of new cases. According to Hogan et al. ${ }^{32}$, the interruption of TB services during the COVID-19 pandemic could increase the number of deaths from TB by up to $20 \%$ in 5 years, possibly due to reduced diagnosis and timely treatment of new cases. According to the Pan American Health Organization (PAHO), the diagnosis of new cases of the disease in the Americas fell between $15 \%$ and $20 \%$ during 2020 when compared to the previous year due to the COVID-19 pandemic, which is a situation that puts the progress towards the end of TB27.

Despite the reduction in the total number of TB notifications, no relationships were found between the variables analyzed and the pandemic. There were also no significant side impacts of COVID-19 on the completeness of the notification fields. Faced with this scenario, the WHO reveals that access to TB services remains a challenge and that achieving global TB targets by 2030 will require technological advances. Rapid tests that are more accessible to the population are needed, in addition to new, safer and more effective vaccines and treatments ${ }^{27}$.

This study has some limitations, such as the use of secondary data from health information systems, which are subject to biases during filling. Assessment of the quality of notifications was not an objective of this study. It is possible that there are cases of underreporting of TB. Notifications came from a single Brazilian region; divergences with other regions of the country may exist. Therefore, it is not recommended to extrapolate the results.

In this study, it was possible to trace the epidemiological profile of the population with TB in the DRS XII in the state of SP in the last 10 years and to verify the impact of the COVID-19 pandemic 
on the reduction of these notifications in 2020. The present study highlights the need to improve surveillance of TB during and after the pandemic. The results presented in this study can help managers and health professionals to make more assertive decisions in the provision of care.

\section{REFERENCES}

1. World Health Organization. Global tuberculosis report 2019 [Internet]. Geneva: WHO; 2019 [cited 2020 Jan 1]. 297 p. Available from:

https://apps.who.int/iris/bitstream/handle/10665/329368/9789241565714-eng.pdf?ua=1

2. World Health Organization. WHO report 2019:global tuberculosis control: surveillance, planning, financing. Geneva: WHO; 2019.

3. Brasil. Ministério da Saúde. PortariaMS/GM no. 204, de 17 de fevereiro de 2016. Define a Lista Nacional de Notificação Compulsória de doenças, agravos e eventos de saúde pública [Internet]. Diário Oficial da União; Brasília; 2016; Seção 1:23. [cited 2020 Sep 9]. Available from: http://bvsms.saude.gov.br/bvs/saudelegis/gm/2016/prt0204_17_02_2016.html

4. Brasil. Ministério da Saúde. Secretaria de Vigilância em Saúde. Doença pelo coronavírus: COVID-19. Brasília: Ministério da Saúde; 2020. (Boletim epidemiológico especial; no. 33).

5. Brasil. Ministério da Saúde. Secretaria de Vigilância em Saúde. Boletim Epidemiológico Tuberculose 2020 [Internet]. Brasília: Ministério da Saúde; 2020 [cited 2019 Jun 1]. Available from: https://www.gov.br/saude/pt-br/media/pdf/2021/marco/24/boletim-tuberculose-2021_24.03/view

6. Brasil. Ministério da Saúde. Secretaria de Vigilância em Saúde. Situação epidemiológica e estratégias de prevenção, controle e eliminação das doenças tropicais negligenciadas no Brasil, 1995 a 2016 [Internet]. Brasília: Ministério da Saúde; 2018 [cited 2019 Jun 1]. (Boletim Epidemiologico, 49). Available from: portalms.saude.gov.br/images/pdf/2018/setembro/05/2018-041.pdf

7. Brasil. Ministério da Saúde. O que é o Coronavírus? (COVID-19) [Internet]. Brasília: Ministério da Saúde; 2020 [cited 2020 Mar 21]. Available from: https://coronavirus.saude.gov.br/.

8. Brasil. Ministério da Saúde. Plataforma Integrada de Vigilância em Saúde. Notificação de casos pelo novo coronavírus (COVID-2019) [Internet]. Brasília: Ministério da Saúde; 2019 [cited 2019 Sep 21]. Available from: http://plataforma.saude.gov.br/novocoronavirus/

9. Aquino EM, et al. Medidas de distanciamento social no controle da pandemia de COVID-19: potenciais impactos e desafios no Brasil. Cien Saude Colet. 2020;25(Suppl 1):2423-46. http://dx.doi.org/10.1590/1413-81232020256.1.10502020. PMid:32520287.

10. Liu Q, Lu P, Shen Y, Li C, Wang J, Zhu L, Lu W, Martinez L. Collateral Impact of the Coronavirus Disease 2019 (COVID-19) - Pandemia no Controle da Tuberculose na Província de Jiangsu, China. Clin Infect Dis. 2021;73(3):542-544.

11. Migliori GB, et al. Worldwide effects of coronavirus disease pandemic on tuberculosis services. Emerg Infect Dis. 2020;26(11):2709-12. https://doi.org/10.3201/eid2611.203163.

12. Kwak N, Hwang SS, Yim JJ. Effect of COVID-19 on tuberculosis notification, South Korea. Emerg Infect Dis. 2020;26(10):2506-8. http://dx.doi.org/10.3201/eid2610.202782. PMid:32672531.

13. von Elm E, Altman DG, Egger M, Pocock SJ, Gøtzsche PC, Vandenbroucke JP, and the STROBE Initiative. The Strengthening the Reporting of Observational Studies in Epidemiology (STROBE) statement: guidelines for reporting observational studies. J Clin Epidemiol. 2008;61(4):344-9. http://dx.doi.org/10.1016/j.jclinepi.2007.11.008. PMid:18313558.

14. Dos Santos Marques LC. Santos De Oliveira, OL, Andrade Pereira M. Perfil clínico, epidemiológico e laboratorial da tuberculose entre 2014 a 2019 no estado da Bahia. Saúde Coletiva (Barueri), 2020;10(57):3523-34. http://dx.doi.org/10.36489/saudecoletiva.2020v10i57p3523-3534.

15. Brasil. Ministério da Saúde. Secretaria de Vigilância em Saúde. Departamento de Vigilância das Doenças Transmissíveis. Brasil livre da tuberculose: plano nacional pelo fim da tuberculose como problema de saúde pública [Internet]. Brasília: Ministério da Saúde; 2019 [cited 2019 Feb 19]. Available from: http://bvsms.saude.gov.br/bvs/publicacoes/brasil_livre_tuberculose_plano_nacional.pdf

16. World Health Organization. Global Tuberculosis Report 2016 [Internet]. Geneva: WHO; 2016 [cited 2021 Apr 10]. Available from: http://www.who.int/tb/publications/global_report/en/

17. World Health Organization. Global Tuberculosis Report 2017 [Internet]. Geneva: WHO; 2017 [cited 2021 Apr 10]. Available from: http://who.int/tb/publications/global_report/en/ 
18. Tavares CM, Cunha AMS, Gomes NMC, Lima ABA, Santos IMR, Acácio MS, Santos DM, Souza CDF. Tendência e caracterização epidemiológica da tuberculose em Alagoas, 2007-2016. Cad Saude Colet. 2020;28(1):107-15. http://dx.doi.org/10.1590/1414-462x202028010381.

19. Macedo LF, Bastos TR, Deprá JVS, Feio LPP, Braga TLGP, Paes ALV. Levantamento epidemiológico e fatores associados à coinfecção tuberculose/HIV no Brasil. Revista Eletrônica Acervo Saúde. 2021;13(1):e5360. http://dx.doi.org/10.25248/reas.e5360.2021

20. Sousa GO, Sales BN, Gomes JGF, Silva MA, Oliveira GAL. Epidemiologia da tuberculose no nordeste do Brasil, 2015-2019. RESEARCH, SOCIETY AND DEVELOPMENT. 2020;9(8):82985403. http://dx.doi.org/10.33448/rsd-v9i8.5403.

21. Santos GM Jr, Santos DO, Gibaut MAM, Bispo TCF. Tuberculose: adesão ao tratamento e os fatores que desencadeiam em abandono. Rev Enfermagem Contemp. 2016;5(2):284-92. http://dx.doi.org/10.17267/2317-3378rec.v5i2.1041.

22. Rodrigues MW, Mello ANC. Tuberculose e escolaridade: uma revisão da literatura. RIAI. 2018;4(2):112. http://dx.doi.org/10.17561/riai.v4.n2.1.

23. Santos KS, Tavares CM, Arcênio RA, Nanque AR, Santos TS, Almeida V. Profile of morbidity and mortality of tuberculosis cases. Rev enferm UFPE on line. 2015;9(5):7789-96. https://doi.org/10.5205/1981-8963- v9i5a10526p7789-7796-2015.

24. Pereira JC, Silva MR, Costa RR, Guimarães MDC, Leite ISC. Profile and follow-up of patients with tuberculosis in a priority city in Brazil. Rev Saude Publica. 2015;49:6. http://dx.doi.org/10.1590/S0034-8910.2015049005470. PMid:25741659.

25. Silva MDG, Bartholomay P, Cruz GO, Garcia PL. Avaliação da qualidade dos dados, oportunidade e aceitabilidade da vigilância da tuberculose nas microrregiões do Brasil. Ciênc Saúde Coletiva. 2017;22(10):3307-19. http://dx.doi.org/10.1590/1413-812320172210.18032017

26. Braga JU. Vigilância epidemiológica e o sistema de informação da tuberculose no Brasil, 2001-2003. Rev Saúde Pública. 2007;;41(1):77-87. https://doi.org/10.1590/S0034-89102007000800011.

27. Organização Pan-Americana de Saúde. OMS afirma que Progresso global no combate à tuberculose está em risco [Internet]. Washington: OPAS; 2020 [cited 2020 Mar 5]. Available from: https://www.paho.org/bra/index.php?option=com_content\&view=article\&id=6307:progressoglobal-no-combate-a-tuberculose-esta-em-risco-afirma-oms\&ltemid=812

28. Cortez AO, Melo AC, Neves LO, Resende KA, Camargos P. Tuberculose no Brasil: um país, múltiplas realidades. J Bras Pneumol. 2021;47(2):e20200119. http://dx.doi.org/10.36416/18063756/e20200119. PMid:33656156.

29. Secretaria Estadual de Saúde de São Paulo. Centro de Vigilância Epidemiológica “Prof. Alexandre Vranjac". Divisão de Tuberculose. Boletim Especial Tuberculose 2006 a 2020 [Internet]. [cited 2020 Mar 5]. Available from: https://www.saude.sp.gov.br/resources/cve-centro-de-vigilanciaepidemiologica/areas-de-vigilancia/tuberculose/doc/boletim2021_especial_tuberculose.pdf

30. Dookie N, Padayatchi N, Naidoo K. Tuberculosis elimination in the Era of COVID-19: a moving target. Clin Infect Dis. 2020;ciaa1400.

31. Mcquaid CF, McCreesh N, Read JM, Sumner T, Houben RMGJ, White RG, Harris RC, and the CMMID COVID-19 Working Group. The potential impact of COVID-19-related disruption on tuberculosis burden. Eur Respir J. 2020;56(2):2001718. http://dx.doi.org/10.1183/13993003.01718-2020. PMid:32513784.

32. Hogan AB, et al. Potential impact of the COVID-19 pandemic on HIV, tuberculosis, and malaria in low-income and middle-income countries: a modelling study. The Lancet Glob Health. 2020;8(9):e1132-e1141. https://doi.org/10.1016/S2214-109X(20)30288-6.

\section{Authors' contributions}

Pontes TAA and Wiens A contributed to the collection, systematization, analysis, interpretation of results and writing of the article; Ramos RA and Scolaro JP, in data collection; Riveros BS in data review, analysis and interpretation of results and Tonin FS in data review, analysis and interpretation of results and writing of the article. All authors have reviewed and approved the final version of the manuscript. 